\title{
FIRST RECORD OF ALBINISM IN THE SWELL SHARK, CEPHALOSCYLLIUM VENTRIOSUM (ELASMOBRANCHII: CARCHARHINIFORMES: SCYLIORHINIDAE)
}

\author{
Edgar E. BECERRIL-GARCÍA, Elena TAMBURIN, Rogelio GONZÁLEZ-ARMAS, \\ and Felipe GALVÁN-MAGAÑA*
}

Instituto Politécnico Nacional, Centro Interdisciplinario de Ciencias Marinas, La Paz, México

\begin{abstract}
Becerril-García E.E., Tamburin E., González-Armas R., Galván-Magaña F. 2017. First record of albinism in the swell shark, Cephaloscyllium ventriosum (Elasmobranchii: Carcharhiniformes: Scyliorhinidae). Acta Ichthyol. Piscat. 47 (2): 201-204.

Abstract. We report the first record of albinism in the swell shark, Cephaloscyllium ventriosum (Garman, 1880). The specimen was caught off the southern part of the Baja California Peninsula, Mexico. The shark had no skin pigmentation and golden-coloured eyes. The pigmentation of its eyes may be related to the previously reported presence of ocular pigments that are different from melanin, and thus not affected by albinism.
\end{abstract}

Keywords: mutation, achromatic, melanin, rhodopsins, chrysopsins

The albinism records on chondrichthyans in Mexico, have been made mostly in the north-west part of the country (De Jesus-Roldan 1990, Bejarano-Álvarez and Galván-Magaña 2013, Escobar-Sánchez et al. 2014). Such cases are scarce in southern Mexico and the affected fish have been caught mostly off the states of Colima (Sandoval-Castillo et al. 2006), Chiapas (Sancho-Vazquez et al. 2015), and Tabasco (Wakida-Kusunoki 2015; Fig. 1). Although these records include several taxa of shark families, there has been no record of albino scyliorhinids in the South or North American continents.

The swell shark, Cephaloscyllium ventriosum (Garman, 1880), is a demersal species of the family Scyliorhinidae (see Compagno et al. 2005) that it is mostly found on algae-covered rock bottoms along the eastern Pacific coast (Schaaf-Da Silva and Ebert 2008, Castro 2011). Swell sharks are usually found at depths from 5 to $37 \mathrm{~m}$, but were recorded at a maximum depth of $457 \mathrm{~m}$ (Compagno et al. 2005). This oviparous shark feeds, during the night, on small reef fishes and benthic invertebrates like cephalopods and crustaceans (Schaaf-Da Silva and Ebert 2008, Castro 2011), and undergoes seasonal vertical migrations as part of its foraging behaviour (Crescitelli et al. 1985). The swell shark can expand its size by swallowing water or air into its coelomic cavity, probably as a defensive response to predators (Nelson and Johnson 1970).

The presently reported shark specimen was caught by a local fisherman using a fishing rod, baited with a piece of black skipjack at a bottom depth of $85 \mathrm{~m}$ and released alive on 28 March 2016 near Cabo San Lucas $\left(22^{\circ} 56^{\prime} \mathrm{N}, 109^{\circ} 46^{\prime} \mathrm{W}\right)$. Before releasing the shark, the fisherman took pictures of it (Fig. 2). The shark specimen was identified (based on Fischer et al. 1995, Compagno et al. 2005) as a female of Cephaloscyllium ventriosum of approximately $84 \mathrm{~cm}$ in total length. Sea surface temperature was $21.1^{\circ} \mathrm{C}$. Early-spring oceanographic conditions at this site, are directly influenced by the

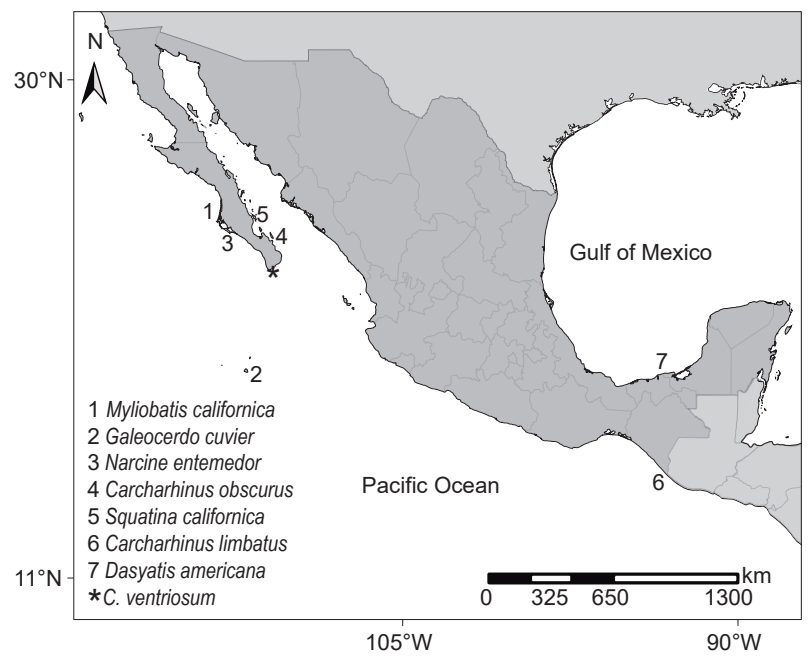

Fig. 1. Records of albino elasmobranchs in Mexico: $1=$ De Jesus-Roldan (1990), 2 = Sandoval-Castillo et al. (2006), 3 = Sandoval-Castillo et al. (2006), 4 = BejaranoÁlvarez and Galván-Magaña (2013), 5 = EscobarSánchez et al. (2014), 6 = Sancho-Vazquez 2007, $7=$ Wakida-Kusunoki 2015, * presently reported finding 
California Current System (Molina-Cruz 1984). This mass of water is characterized by a mean temperature of $\angle 22^{\circ} \mathrm{C}$, a salinity of $34 \%{ }^{*}$, and upwelling events that promote high levels of primary productivity (MolinaCruz 1984). Although the presence of the swell shark is considered as rare in the fishery landings of southern Baja California Peninsula (Ramírez-Amaro et al. 2013), it can be found due to the suitable environmental conditions and food availability, during this specific time of the year (Molina-Cruz 1984).

Albinism is an autosomal recessive disorder affecting the production of melanin and caused by the absence or defect of tyrosinase (Wang et al. 2007, Bigman et al. 2015). This condition manifests as a lack of pigmentation in the tissues or organs containing melanin, and has been shown to occur in chondrichthyans with total or partial albinism (Clark 2002, Wang et al. 2007, Reum et al. 2008, Bigman et al. 2015). Traditionally, the main features to describe total albinism are a totally unpigmented body and red eyes, while in partial albinism, this mutation only affects a part of the body and normal retinal pigmentation is observed (Mnasri et al. 2010, Lipej et al. 2011, Diatta et al. 2013). However, the normality of retinal pigmentation should be defined when relating to albinism, and just be considered in species that present melanin as the primal visual pigment.

Cephaloscyllium ventriosum - the shark presented in this study, had dark golden-coloured eyes and no skin pigmentation. According to Crescitelli et al. (1985), this species has pigments other than melanin in its eyes, specifically reddish-purple rhodopsin and the goldencoloured chrysopsin, which are also found in deep-sea fishes (Denton and Warren 1956, Crescitelli et al. 1985, Crescitelli 1991). Because the albinism affects the presence of melanin by a defect of tyrosinase (Wang et al. 2007), this study constitutes a record of full albinism in the swell shark, due to chrysopsin and rhodopsin, indeed, are not synthetized from tyrosinase, but from a derivative of vitamin A (Crescitelli et al. 1985, Wang et al. 2007, Cohen 2012). In this case, the albinism should not affect the eyes, that naturally do not have melanin (Wang et al. 2007, Cohen 2012).

The albino swell shark's visual capacity would not be affected significantly, with other pigments such as rhodopsins being used during vertical migration to the surface, and chrysopsins, while in deeper and therefore

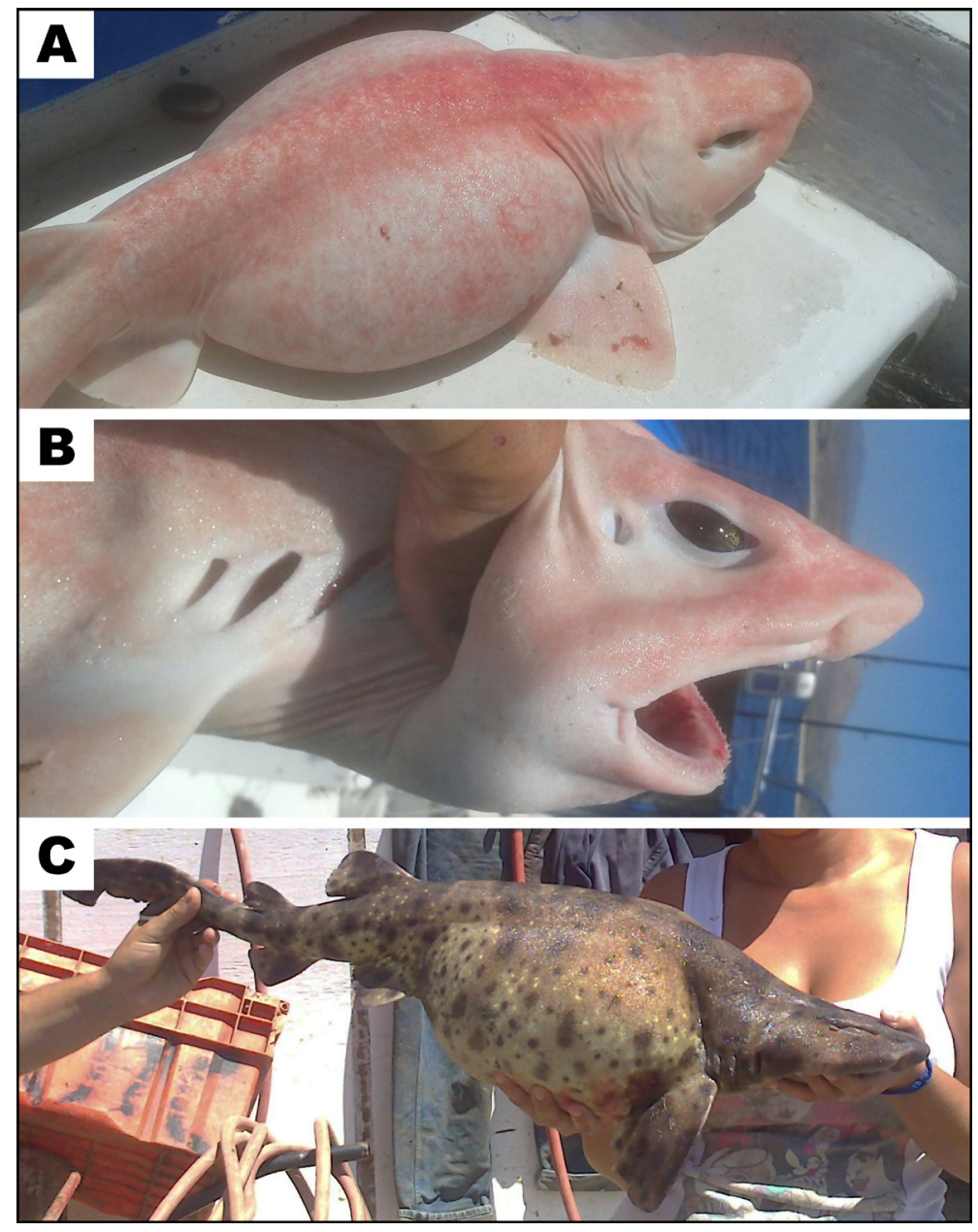

Fig. 2. Albino swell shark caught near Cabo San Lucas, Mexico (A, B), and example of specimen with normal pigmentation (C) (photographs by Jaime Rendón)

"In the wake of the growing criticism of the Practical Salinity Scale concept (and especially PSU as a "unit"), Acta Ichthyologica et Piscatoria is in favour of expressing salinity in parts per thousand (\%), regardless if a direct or indirect method was employed to determine the water salinity. 
darker environments (Denton and Warren 1956, 1957, Crescitelli et al. 1985, Compagno et al. 2005). Because its visual acuity and ability to see bioluminescence would not depend mainly on melanin (Wang et al. 2007, Sparks et al. 2014, Gruber et al. 2016), social interactions with other swell sharks would be possible as well, as was previously suggested for albino elasmobranchs with yellow-orange eyes, caught either in interspecific aggregations (De JesusRoldan 1990) or swimming alone, but with apparently healthy status (Clark 2002, Sandoval-Castillo et al. 2006, Reum et al. 2008, Lipej et al. 2011, Bigman et al. 2015, Wakida-Kusunoki 2015).

The specimen of Cephaloscyllium ventriosum presented here was considered a mature female, according to Ramírez-Amaro et al. (2013). Catching the specimen alive means that it has been able to survive in this environment and avoid predators, possibly by hiding in rocky crevices, which is known a typical behaviour of this fish (Nelson and Johnson 1970, Compagno et al. 2005). However, the implications of the lack of melanin for the albino's body and its capacity for bioluminescence, and possible impacts on its behaviour, are unknown and beyond the scope of this study. Nevertheless, the presence of an albino shark of this size is proof that the recessive genes for albinism are maintained and inherited to the offspring of $C$. ventriosum, as occurs in other vertebrates (Clark 2002, Bigman et al. 2015).

\section{ACKNOWLEDGEMENTS}

We especially thank Jaime Rendón, captain of the boat Dr. Fish, for all the information and photographs provided. We also thank Nicole Reguera-Rozaud for preparing the figures, Isabelle Gamache for the English review, the Instituto Politécnico Nacional for funding through grants from the COFAA (Comisión de Operación y Fomento de Actividades Académicas), and the EDI (Estímulo al Desempeño de los Investigadores). EEBG and ET thank CONACyT (Consejo Nacional de Ciencia y Tecnología) for the scholarships provided.

\section{REFERENCES}

Bejarano-Álvarez O.M., Galván-Magaña F. 2013. First report of an embryonic dusky shark (Carcharhinus obscurus) with cyclopia and other abnormalities. Marine Biodiversity Records 6: e11. DOI: $10.1017 / \mathrm{S} 1755267212001236$

Bigman J.S., Knuckey J.D.S., Ebert D.A. 2015. Color aberrations in chondrichthyan fishes: First records in the genus Bathyraja (Chondrichthyes: Rajiformes: Arhynchobatidae). Marine Biodiversity 46 (3): 579-587. DOI: $10.1007 / \mathrm{s} 12526-015-0403-\mathrm{z}$

Castro J.I. 2011. The sharks of North America. Oxford University Press, Oxford, UK.

Clark S. 2002. First report of albinism in the whitespotted bamboo shark, Chiloscyllium plagiosum (Orectolobiformes: Hemiscyllidae), with a review of reported color aberrations in elasmobranchs. Zoo Biology 21 (6): 519-524.

DOI: $\underline{10.1002 / \text { zoo. } 10068}$
Cohen J.L. 2012. [Chapter 14] Vision in elasmobranchs. Pp. 465-490. In: Douglas R., Djamgoz M. (eds.) The visual system of fish. Chapman and Hall, Torquay, UK. DOI: $\underline{10.1007 / 978-94-009-0411-8}$

Compagno L.J.V., Dando M., Fowler S.L. 2005. Sharks of the World. Princeton University Press, Princeton, NJ, USA.

Crescitelli F. 1991. Adaptations of visual pigments to the photic environment of the deep sea. Journal of Experimental Zoology 5 (S5): 66-75. DOI: $\underline{10.1002 / j e z .1402560510}$

Crescitelli F., McFall-Ngai M., Horwitz J. 1985. The visual pigment sensitivity hypothesis: Further evidence from fishes of varying habitats. Journal of Comparative Physiology A 157 (3): 323-333. DOI: $10.1007 / \mathrm{BF} 00618122$

De Jesus-Roldan M. 1990. An albino bat ray, Myliobatis californica, from the pacific coast of Baja California Sur, Mexico. California Fish and Game 76 (2): 126127.

Denton E.J., Warren F.J. 1956. Visual pigments of the deep-sea fish. Nature 178 (4541): 1059.

DOI: $\underline{10.1038 / 1781059 \mathrm{a} 0}$

Denton E.J., Warren F.J. 1957. The photosensitive pigments in the retinae of deep-sea fish. Journal of the Marine Biological Association of the United Kingdom 36 (3): 651-662. DOI: $10.1017 / \mathrm{S} 0025315400025911$

Diatta Y., Reynaud C., Capapé C. 2013. First case of albinism recorded in striped panray Zanobatus schoenleinii (Chondrichthyes: Platyrhinidae) from the coast of Senegal (eastern tropical Atlantic). Journal of Ichthyology 53 (11): 1007-1012.

DOI: $10.1134 / \mathrm{S} 0032945213110118$

Escobar-Sánchez O., Moreno-Sánchez X.G., AguilarCruz C.A., Abitia-Cárdenas L.A. 2014. First case of synophtalmia and albinism in the Pacific angel shark Squatina californica. Journal of Fish Biology 85 (2): 494-501. DOI: $10.1111 / \mathrm{jfb} .12412$

Fischer W., Krupp F., Schneider W., Sommer C., Carpenter K.E., Niem V.H. 1995. Guía FAO para la identificación de especies para los fines de la pesca. Pacífico centro - oriental. Volumen II. VertebradosParte 1. FAO, Rome.

Gruber D.F., Loew E.R., Deheyn D.D., Akkaynak D., Gaffney J.P., Smith W.L., Davis M.P., Stern J.H., Pieribone V.A., Sparks J.S. 2016. Biofluorescence in catsharks (Scyliorhinidae): fundamental description and relevance for elasmobranch visual ecology. Scientific Reports 6: article No. 24751. DOI: $10.1038 /$ srep24751

Lipej L., Mavric B., Ziza V., Capapé C. 2011. First case of albinism recorded in the marble electric ray Torpedo marmorata (Chondrichthyes: Torpedinidae). Cahiers de Biologie Marine 52: 261—267.

Mnasri N., El Kamel O., Boumaïza M. 2010. Atypical coloration in small-spotted catsharks Scyliorhinus canicula (Chondrichthyes: Scyliorhinidae) caught 
off northern Tunisian Coast (central Mediterranean). Annales, Series Historia Naturalis 20 (1): 47-52.

Molina-Cruz A. 1984. Evolución oceanográfica de la boca del Golfo de California. Anales del Instituto de Ciencias del Mar y Limnología 3 (2): 95-120.

Nelson D.R., Johnson R.H. 1970. Diel activity rhythms in the nocturnal, bottom-dwelling sharks, Heterodontus francisci and Cephaloscyllium ventriosum. Copeia 1970 (4): 732-739.

DOI: $\underline{10.2307 / 1442315}$

Ramírez-Amaro S.R., Cartamil D., Galván-Magaña F., González-Barba G., Graham J.B., CarreraFernández M., Escobar-Sánchez O., SosaNishizaki O., Rochin-Alamillo A. 2013. The artisanal elasmobranch fishery of the Pacific coast of Baja California Sur, Mexico, management implications. Scientia Marina 77 (3): 473-487. DOI: $10.3989 /$ scimar.03817.05A

Reum J.C.P., Paulsen C.E., Pietsch T.W., Parker-Setter S.L. 2008. First record of an albino chimaeriform fish, Hydrolagus colliei. Northwestern Naturalist 89 (1): 60-62. DOI: $\underline{\text { 10.1898/1051-1733(2008)89[60:FROAAC]2.0.CO;2 }}$

Sancho-Vazquez F., Del Moral-Flores L.F., MendozaVargas O.U. 2015. Albinismo parcial en un embrión de tiburón puntas negras, Carcharhinus limbatus (Carcharhinidae: Chondrichthyes) del Pacífico oriental. Latin American Journal of Aquatic Research 43 (1): 274-276.

DOI: $10.3856 /$ vol43-issuel-fulltext-25
Sandoval-Castillo J., Mariano-Melendez E., VillavicenciaGarayzar C. 2006. New records of albinism in two elasmobranchs: the tiger shark Galeocerdo cuvier and the giant electric ray Narcine entemedor. Cybium 30 (2): 191-192.

Schaaf-Da Silva J.A., Ebert D.A. 2008. A re-description of the eastern Pacific swellshark, Cephaloscyllium ventriosum (Garman 1880) (Chondrichthyes: Carcharhiniformes: Scyliorhinidae), with comments on the status of C. uter (Jordan et Gilbert 1896). Zootaxa 1872: 59-68.

Sparks J.S., Schelly R.C., Smith W.L., Davis M.P., Tchernov D., Pieribone V.A., Gruber D.F. 2014. The covert world of fish biofluorescence: A phylogenetically widespread and phenotypically variable phenomenon. PloS ONE 9 (1): e83259.

DOI: 10.1371 /journal.pone.0083259

Wakida-Kusunoki A.T. 2015. First record of total albinism in southern stingray Dasyatis americana. Revista de Biología Marina y Oceanografía 50 (1): 135-139.

DOI: $10.4067 / \mathrm{S} 0718-19572015000100011$

Wang J., Hou L., Zhang R., Zhao X., Jiang L., Sun W., An J., Li X. 2007. The tyrosinase gene family and albinism in fish. Chinese Journal of Oceanology and Limnology 25 (2): 191-198.

DOI: $\underline{10.1007 / \mathrm{s} 00343-007-0191-9}$

Received: 5 February 2017

Accepted: 9 March 2017

Published electronically: 30 June 2017 